\title{
Wykonujący charakter rządowego projektu ustawy o zmianie ustawy - Prawo własności przemysłowej ${ }^{1}$
}

\begin{abstract}
Implementing nature of the Governmental Bill Amending the Act on the Industrial Property Law: The discussed amendment of the act is aimed at the implementation of EU law. The EU directive being implemented aims to approximate the laws of the Member States relating to trademarks. The author assesses which provisions of the bill implement the directive, as well as which ones extend its provisions to other areas of law that are not related to European Union law.
\end{abstract}

Keywords: regulatory impact assessment, bill, European Union, Patent Office, property, trademarks

Słowa kluczowe: ocena skutków regulacji, projekt ustawy, Unia Europejska, Urząd Patentowy, własność, znaki towarowe

Ekspert ds. legislacji BAS • bartosz.pawlowski@sejm.gov.pl • https://orcid.org/0000-0002-8764-6474

\section{Przedmiot opinii}

Zgodnie z deklaracją Rady Ministrów projekt ustawy o zmianie ustawy - Prawo własności przemysłowej ma na celu wykonanie prawa Unii Europejskiej. Z pierwszego zdania uzasadnienia projektu wynika, że chodzi o implementację do prawa polskiego postanowień dyrektywy Parlamentu Europejskiego i Rady (UE) 2015/2436 z 16 grudnia 2015 r., mającej na celu zbliżenie ustawodawstw państw członkowskich odnoszących się do znaków towarowych ${ }^{2}$. Niniejsza opinia ma służyć ustaleniu, czy deklaracja o wykonującym charakterze projektu ustawy jest uzasadniona - które przepisy projektu implementują dyrektywę, które rozciągają jej postanowienia na inne obszary prawa, a które nie są związane z prawem Unii Europejskiej.

1 Opinia na temat wykonujacego charakteru rzadowego projektu ustawy o zmianie ustawy - Prawo własności przemysłowej (druk 3107) sporządzona 15 stycznia 2019 r. na zlecenie Biura Analiz Sejmowych; BAS-WAPEiM 79/19.

2 Dz.Urz. UE L 336 z 23 grudnia 2015 r., s. 1; dalej: dyrektywa lub dyrektywa 2015/2436. 


\section{Treść dyrektywy}

Dyrektywa 2015/2436 z dniem 15 stycznia 2019 r. uchyla i zastępuje dyrektywę Parlamentu Europejskiego i Rady 2008/95/WE z 22 października 2008 r., mającą na celu zbliżenie ustawodawstw państw członkowskich odnoszących się do znaków towarowych ${ }^{3}$.

Nadrzędnym celem dyrektywy 2015/2436 jest tworzenie i rozwijanie dobrze funkcjonującego rynku wewnętrznego oraz ułatwienie rejestracji i ochrony znaków towarowych oraz zarządzanie nimi w Unii Europejskiej w celu wspierania konkurencyjności (pkt 42 preambuły do dyrektywy).

Jak stwierdzono w uzasadnieniu projektu dyrektywy ${ }^{4}$, ustawodawstwo państw członkowskich dotyczące znaków towarowych zostało częściowo zharmonizowane dyrektywą Rady 89/104/EWG z 21 grudnia 1988 r., ujednoliconą jako dyrektywa 2008/95/WE. Równolegle i w powiązaniu z krajowymi systemami znaków towarowych rozporządzeniem Rady (WE) nr 40/94 z 20 grudnia 1993 r. w sprawie wspólnotowego znaku towarowego, ujednoliconym jako rozporządzenie (WE) nr 207/20095, ustanowiono niezależny system rejestracji jednolitych praw wywołujących ten sam skutek w całej UE. W związku z tym utworzono Urząd Harmonizacji Rynku Wewnętrznego odpowiedzialny za rejestrację wspólnotowych znaków towarowych i administrowanie nimi (z dniem 15 marca 2016 r. Urząd został przekształcony w Urząd Unii Europejskiej ds. Własności Intelektualnej; dalej: EUIPO)

Wraz z projektem dyrektywy Komisja przedstawiła projekt zmian rozporządzenia dotyczącego wspólnotowego znaku towarowego ${ }^{6}$. Oba dokumenty Komisja traktowała jako pakiet. Ich wspólnym celem było pobudzenie innowacji i wzrostu gospodarczego poprzez zwiększenie dostępności dla przedsiębiorstw i skuteczności systemów rejestracji znaków towarowych w całej UE dzięki zmniejszeniu związanych z nimi kosztów i złożoności tych systemów, a także zwiększeniu szybkości obsługi, przewidywalności i bezpieczeństwa prawnego. Te zmiany stanowią, zdaniem Komisji, uzupełnienie starań mających na celu zapewnienie współistnienia i komplementarności systemu unijnego i krajowych systemów rejestracji znaków towarowych. Dyrektywa ma w szczególności następujące zadania:

- unowocześnienie i udoskonalenie istniejących dotychczasowych przepisów dyrektywy 2008/95/WE poprzez zmianę przestarzałych przepisów, zwiększe-

Dz.Urz. UE L 299 z 8 listopada 2008 r., s. 25.

$\operatorname{COM}(2013) 162$ final.

5 Rozporządzenie zostało z dniem 1 października 2017 r. uchylone i zastąpione rozporządzeniem Parlamentu Europejskiego i Rady (UE) 2017/1001 z 14 czerwca 2017 r. w sprawie znaku towarowego Unii Europejskiej; Dz.Urz. UE L 154 z 16 czerwca 2017 r., s. 1.

6 Zob. obowiązujące rozporządzenie 2017/1001. 
nie pewności prawa oraz uściślenie praw wynikających ze znaków towarowych pod względem ich zakresu i ograniczeń,

- osiągnięcie większego zbliżenia krajowych przepisów i procedur dotyczących znaków towarowych w celu zwiększenia ich spójności z systemem wspólnotowego znaku towarowego,

- usprawnianie współpracy między urzędami z państw członkowskich a EUIPO w celu upowszechniania harmonizacji praktyk i opracowywania wspólnych narzędzi poprzez ustanowienie podstawy prawnej tej współpracy.

Dyrektywa m.in. określa oznaczenia, z których może składać się znak towarowy. Należy odnotować rezygnację z konieczności przedstawienia znaku towarowego w sposób graficzny. Dyrektywa wyznacza także podstawy prawne odmowy rejestracji lub unieważnienia znaku towarowego, prawa wynikające ze znaku towarowego, ograniczenie skutków znaku towarowego, wyczerpanie praw wynikających ze znaku, wygaśnięcie praw ze znaku towarowego, przeniesienie znaku towarowego, znaki gwarancyjne lub certyfikujące i znaki wspólne, procedury zgłaszania i rejestracji znaków oraz współpracę administracyjną krajowych urzędów ds. znaków towarowych ze sobą oraz z EUIPO.

Postanowienia dyrektywy, które stanowią nowość w porównaniu z dyrektywą 2008/95/WE, powinny zostać implementowane do krajowych porządków prawnych do dnia 14 stycznia 2019 r. (art. 54 ust. 1 akapit pierwszy zdanie pierwsze w związku z pkt 45 preambuły do dyrektywy). Natomiast postanowienia art. 45 dyrektywy, dotyczące krajowych procedur stwierdzenia wygaśnięcia lub unieważnienia znaku towarowego, powinny zostać implementowane do 14 stycznia $2023 \mathrm{r}$.

\section{Projekt ustawy jako projekt ustawy wykonującej prawo Unii Europejskiej}

Zgodnie z art. 288 Traktatu o funkcjonowaniu Unii Europejskiej dyrektywa wiąże każde państwo członkowskie, do którego jest kierowana, w odniesieniu do rezultatu, który ma być osiągnięty, pozostawiając jednak organom krajowym swobodę wyboru formy i środków.

Artykuł 18 ust. 2 ustawy z 8 października 2010 r. o współpracy Rady Ministrów z Sejmem i Senatem w sprawach związanych z członkostwem Rzeczypospolitej Polskiej w Unii Europejskiej (Dz.U. nr 213, poz. 1395; dalej: ustawa kooperacyjna) reguluje współpracę Rady Ministrów z Sejmem w zakresie tworzenia prawa polskiego wykonującego prawo Unii Europejskiej. Zgodnie z art. 18 ust. 2 Rada Ministrów wnosi do Sejmu projekt ustawy wykonującej prawo Unii Europejskiej nie później niż na 5 miesięcy przed upływem terminu wykonania, wynikającego z prawa Unii Europejskiej. W przypadku dyrektywy 2015/2436 
termin jej implementacji upłynął 14 stycznia 2019 r. Projekt został przesłany do Sejmu 11 grudnia 2018 r. Wobec powyższego należy stwierdzić, że Rada Ministrów naruszyła art. 18 ust. 2 ustawy kooperacyjnej. Z uzasadnienia projektu nie wynika, by spełnione zostały przesłanki odstąpienia od tego terminu przewidziane w art. 18 ust. 3 tejże ustawy.

Uzupełnieniem przywołanego przepisu ustawy kooperacyjnej są przepisy art. 95a-95f regulaminu Sejmu, które regulują postępowanie z projektami ustaw wykonujących prawo Unii Europejskiej. Zgodnie z art. 95a ust. 2 Rada Ministrów, wnosząc projekt ustawy, deklaruje, czy jest to projekt ustawy wykonującej prawo Unii Europejskiej.

Ustawa kooperacyjna ani regulamin Sejmu nie definiują pojęcia projektu ustawy wykonującej prawo Unii Europejskiej. W szczególności nie określają, czy taki projekt, poza przepisami ściśle związanymi z prawem Unii Europejskiej, może zawierać także inne postanowienia. Zgodnie $\mathrm{z}$ informacją zawartą w dołączonym do projektu ustawy Raporcie z konsultacji publicznych projektu ustawy o zmianie ustawy - Prawo własności przemysłowej z pierwotnego projektu ustawy wyodrębniono przepisy stanowiące implementację dyrektywy 2015/2436 . Zatem, z założenia, opiniowany projekt ustawy ma na celu wyłącznie implementację dyrektywy.

\section{Ocena wykonującego charakteru przepisów projektu}

Poniżej dokonana zostanie ocena wykonującego charakteru poszczególnych przepisów projektu ustawy. Brak dodatkowych uwag dotyczących poszczególnych przepisów projektu oznacza, że dokonują one prawidłowej implementacji wskazanych przepisów prawa UE.

Zmiana art. 120 ust. 1 i 2 ustawy z 30 czerwca 2000 r. - Prawo własności przemysłowej (t.j. Dz.U. 2017, poz. 776, ze zm.; dalej: u.p.w.p.) ma na celu implementację art. 3 dyrektywy. Przepis dotyczy definicji znaku towarowego. Zmiana polega na rezygnacji $\mathrm{z}$ wymogu graficznej formy znaku.

Zmiany art. $129^{1}$ u.p.w.p.:

Ust. 1 pkt 5 - ma na celu implementację art. 4 ust. 1 lit. e dyrektywy. Przepis dotyczy bezwzględnych podstaw odmowy rejestracji lub unieważnienia znaku towarowego.

Ust. 1 pkt 8 - stanowi implementację art. 4 ust. 3 dyrektywy. Jest to przepis fakultatywny, co do którego państwa mogą podjąć decyzję, czy decydują się na implementację. Należy jednak odnotować, że obowiązujący przepis ustawy - Pra-

Zgodnie z informacją umieszczoną na stronach internetowych Rządowego Centrum Legislacji projekt został wyodrębniony z projektu ustawy o zmianie ustawy - Prawo własności przemysłowej (UD311, https://legislacja.rcl.gov.pl/projekt/12305951). 
wo własności przemysłowej w zasadzie jest odpowiednikiem przepisu dyrektywy. Zmiana ma na celu dostosowanie brzmienia przepisu ustawowego do przepisu dyrektywy. Przepis dotyczy odmowy rejestracji lub unieważnienia rejestracji znaku towarowego zawierającego oznaczenie o wysokiej wartości symbolicznej (obowiązujący przepis ustawy odnosi się do znaku zawierającego element będący symbolem).

Ust. 1 pkt 13 - ma na celu implementację art. 4 ust. 1 lit. 1 dyrektywy. Przepis dotyczy bezwzględnych podstaw odmowy rejestracji lub unieważnienia znaku towarowego.

Ust. 4 - ma na celu implementację art. 4 ust. 1 lit. i dyrektywy. Przepis dotyczy bezwzględnych podstaw odmowy rejestracji lub unieważnienia znaku towarowego.

Zmiana art. 132 $^{1}$ u.p.w.p. ma na celu implementację art. 5 ust. 3 lit. c dyrektywy. Przepis dotyczy względnych przyczyn odmowy rejestracji lub unieważnienia znaku towarowego.

Zmiana tytułu rozdziału $2 \mathrm{w}$ dziale I, tytule III - jest zmianą redakcyjną, wynikającą ze zmian dalszych przepisów implementujących postanowienia dyrektywy.

Zmiana art. 136 u.p.w.p. ma na celu implementację art. 27 lit. b, art. 29 i art. 30 dyrektywy. Przepis dotyczy wspólnych znaków towarowych. Należy odnotować, że proponowane brzmienie nowelizowanego przepisu różni się od jego wersji przytoczonej w tabeli zbieżności.

Dodanie art. 136 $^{1}$ u.p.w.p. ma na celu implementację art. 31 dyrektywy. Przepis dotyczy przyczyn odmowy rejestracji wspólnego znaku towarowego.

Dodanie art. $136^{2}$ i art. $136^{3}$ u.p.w.p. ma na celu implementację art. 27 lit. a i art. 28 dyrektywy. Są to przepisy fakultatywne - państwa członkowskie mogą zdecydować, czy uregulują w swoich krajowych porządkach prawnych instytucję znaków gwarancyjnych lub certyfikujących.

Uchylenie art. 137 u.p.w.p. jest konsekwencją implementacji postanowień dyrektywy dotyczących znaków gwarancyjnych.

\section{Zmiany art. 138 u.p.w.p.:}

Ust. 3 i 4 mają na celu implementację art. 30 ust. 1 i 2 dyrektywy. Przepisy dotyczą rejestracji i regulaminu używania wspólnego znaku towarowego.

Ust. 5 ma na celu implementację art. 33 dyrektywy. Przepis dotyczy rejestracji zmian regulaminu używania wspólnego znaku towarowego.

Ust. 6 i 7 - nie wynikają bezpośrednio z postanowień dyrektywy. Można jednak przyjąć, że mieszczą się w zakresie art. 28 ust. 3 dyrektywy i nie są niezgodne $\mathrm{z}$ art. 37 dyrektywy. Przepisy te są częścią ustawowej regulacji gwarancyjnych znaków towarowych, która - zgodnie z dyrektywą - jest regulacją fakultatywną.

Zmiana art. 142 u.p.w.p. stanowi doprecyzowanie obowiązującego przepisu, przez wskazanie, że chodzi o poprawki w dokumentacji zgłoszenia znaku towarowego. 
Dodanie art. $144^{2}$ u.p.w.p. ma na celu implementację art. 39 ust. 4 dyrektywy. Przepis dotyczy konsekwencji braku doprecyzowania, na żądanie Urzędu Patentowego, zgłoszenia znaku towarowego.

Zmiany art. 145 u.p.w.p. są konsekwencją i uzupełnieniem wprowadzenia art. $136^{1}$ i art. $136^{3}$ u.p.w.p. dotyczących wspólnego znaku towarowego i gwarancyjnego znaku towarowego, które implementują postanowienia dyrektywy. Przepisy te mają na celu implementację art. 28 i 31 dyrektywy.

Zmiany art. $146^{1}$ u.p.w.p. są konsekwencją i uzupełnieniem wprowadzenia art. $136^{1}$ i art. $136^{3}$ dotyczących wspólnego znaku towarowego i gwarancyjnego znaku towarowego, które implementują postanowienia dyrektywy. Zmiana dotycząca ust. 4 ma na celu implementację art. 40 dyrektywy, który jest przepisem fakultatywnym i zezwala państwom członkowskim na dopuszczenie zgłaszania uwag osób trzecich w stosunku do rejestracji znaku towarowego.

Zmiany przewidziane w art. 1 pkt 13-22 projektu ustawy, a dotyczące dodania art. $152^{1 \mathrm{aa}}$, art. $152^{6 \mathrm{c}}$, art. $152^{7 \mathrm{a}}$ u.p.w.p., uchylenia art. $152^{5} \mathrm{i}$ art. $152^{6}$ u.p.w.p. oraz zmiany brzmienia art. $152^{2}$, art. $152^{3}$, art. $152^{6 a}$, art. $152^{7}$, art. $152^{14}$, art. $152^{15}$ u.p.w.p. dotyczą międzynarodowych znaków towarowych. Ich związek z dyrektywą jest pośredni. Zgodnie z art. 1 dyrektywy ma ona zastosowanie do każdego znaku towarowego dla towarów lub usług, który jest indywidualnym znakiem towarowym, znakiem gwarancyjnym lub certyfikującym lub znakiem wspólnym zarejestrowanym lub zgłoszonym w państwie członkowskim lub w Urzędzie Własności Intelektualnej Państw Beneluksu lub którego rejestracja międzynarodowa ma skutek w państwie członkowskim. Należy jednak odnotować, że zmiana art. $152^{15}$ u.p.w.p. ma na celu implementację art. 16 ust. 3 dyrektywy, który reguluje termin rozpoczęcia używania międzynarodowego znaku towarowego.

Zmiany te mają na celu doprowadzenie do zgodności ustawy - Prawo własności przemysłowej z porozumieniem madryckim o międzynarodowej rejestracji znaków z 14 kwietnia 1891 r. (Dz.U. 1993, nr 116, poz. 514 i 515) oraz protokołem do porozumienia madryckiego o międzynarodowej rejestracji znaków, sporządzonym w Madrycie 27 czerwca 1989 r. (Dz.U. 2003, nr 13, poz. 129 i 130). Unia Europejska jest stroną protokołu do porozumienia madryckiego ${ }^{8}$.

Zmiana art. $152^{17}$ u.p.w.p. ma na celu implementację art. 43 ust. 2 dyrektywy. Przepis dotyczy podmiotów uprawnionych do wnoszenia sprzeciwu.

Zmiana art. $152^{22}$ u.p.w.p. dotyczy usunięcia błędu legislacyjnego dotyczącego wskazania podmiotu właściwego do rozpatrzenia wniosków o ponowne

8 Decyzja Rady z 27 października 2003 r. zatwierdzająca przystąpienie Wspólnoty Europejskiej do protokołu odnoszącego się do porozumienia madryckiego o międzynarodowej rejestracji znaków, przyjętego w Madrycie 27 czerwca 1989 r. (2003/793/ WE), Dz.Urz. WE L 296 z 14 listopada 2003 r., s. 20. Unia Europejska nie może być stroną porozumienia madryckiego o międzynarodowej rejestracji znaków, gdyż umowa ta nie przewiduje przystąpienia do niej organizacji międzynarodowych. 
rozpatrzenie sprawy rozstrzygniętej decyzją Urzędu Patentowego, wydaną po rozpatrzeniu sprzeciwu. Przepis ten służy implementacji art. 43 dyrektywy, który dotyczy wydajnej i szybkiej procedury administracyjnej pozwalającej na wniesienie sprzeciwu wobec rejestracji zgłoszenia znaku towarowego.

Zmiana art. $152^{23}$ u.p.w.p. dotyczy kosztów postępowania w sprawie sprzeciwu. Regulacja postępowania w sprawie sprzeciwu wynika $\mathrm{z}$ konieczności implementacji art. 43 dyrektywy. Jednak kwestia dotycząca kosztów tego postępowania nie jest bezpośrednio związana $\mathrm{z}$ dyrektywą.

Zmiany art. 153 u.p.w.p. mają na celu implementację art. 49 dyrektywy. Przepisy dotyczą przedłużenia prawa ochronnego na znak towarowy.

Zmiany art. 156 u.p.w.p. mają na celu implementację art. 14 dyrektywy. Przepisy dotyczą ograniczeń skutków znaku towarowego.

Zmiana art. 157 u.p.w.p. ma na celu implementację art. 17 dyrektywy. Przepisy dotyczą konsekwencji nieużywania znaku towarowego.

Uchylenie art. 158 u.p.w.p. ma na celu doprowadzenie do zgodności nowelizowanej ustawy $z$ art. 10 ust. 3 dyrektywy. Przepis dotyczy praw wynikających ze znaku.

Zmiana art. 161 u.p.w.p. ma na celu implementację art. 13 w związku $\mathrm{z}$ art. 5 ust. 3 lit. b dyrektywy. Przepisy dotyczą zakazu używania znaku towarowego zarejestrowanego na rzecz agenta lub przedstawiciela.

Zmiana art. 162 u.p.w.p. ma na celu implementację art. 22 dyrektywy. Przepis dotyczy przeniesienia prawa ochronnego na znak towarowy.

Zmiana art. 162 $^{1}$ u.p.w.p. ma na celu implementację art. 41 dyrektywy. Przepis dotyczy podziału prawa ochronnego na znak towarowy.

Zmiany art. 163 u.p.w.p. mają na celu implementację art. 25 dyrektywy. Przepis dotyczy udzielania licencji.

Zmiany art. 164 u.p.w.p. w związku ze zmianami art. 169 u.p.w.p. mają na celu implementację art. 45 dyrektywy. Przepisy dotyczą unieważnienia i wygaśnięcia prawa ochronnego na znak towarowy. Proponowane zmiany są związane ze zmianami dotyczącymi wspólnych i gwarancyjnych znaków towarowych.

Zmiany art. 165 u.p.w.p. mają na celu implementację art. 8 i art. 36 dyrektywy. Przepisy dotyczą przesłanek unieważnienia znaku towarowego.

Zmiany art. 166 u.p.w.p. mają na celu implementację art. 46 dyrektywy. Przepis dotyczy nieużywania znaku jako zarzutu w postępowaniu $\mathrm{w}$ sprawie unieważnienia znaku towarowego.

Zmiany art. 169 u.p.w.p. mają na celu implementację art. 32, 33, 35 i 45 dyrektywy. Przepisy dotyczą wygaśnięcia prawa ochronnego na znak towarowy.

Zmiany art. 172 u.p.w.p. mają na celu implementację art. 47 dyrektywy. Przepis dotyczy momentu wygaśnięcia prawa ochronnego na znak towarowy.

Dodanie art. $172^{1}$ u.p.w.p. ma na celu implementację art. 6 dyrektywy. Przepis dotyczy sytuacji, gdy przedmiotem wniosku o unieważnienie lub stwierdzenie wygaśnięcia prawa ochronnego jest znak towarowy, na podstawie którego zastrzeżone jest starszeństwo znaku towarowego Unii Europejskiej. 
Zmiany art. 224 u.p.w.p. mają na celu implementację art. 49 dyrektywy. Przepis dotyczy informowania uprawnionego z prawa ochronnego na znak towarowy o zbliżającym się terminie uiszczenia opłaty za kolejny okres ochronny. Należy odnotować, że dyrektywa dotyczy tylko znaków towarowych, natomiast projekt (proponowany art. 224 ust. $2^{2}$ u.p.w.p.) rozciąga tę regulację na inne prawa przewidziane ustawą.

Zmiana art. $233^{1}$ u.p.w.p. dotyczy ogłoszeń zamieszczanych w Biuletynie Urzędu Patentowego. Zmiana nie jest bezpośrednio związana z dyrektywą. Jest konsekwencją proponowanych zmian dotyczących międzynarodowych znaków towarowych.

Zmiany art. $241^{1}$ u.p.w.p. dotyczą formy zawiadomień przewidzianych w art. 224 u.p.w.p., który implementuje art. 49 dyrektywy.

Zmiana art. 261 u.p.w.p. ma na celu usunięcie błędu legislacyjnego przez dodanie do zadań Urzędu Patentowego rozpatrywania sprzeciwów w zakresie określonym ustawą. Procedura wnoszenia sprzeciwów jest uregulowana w art. 43 dyrektywy, implementowanym do prawa polskiego przez art. $152^{17}$ i n. u.p.w.p.

Zmiana art. 264 u.p.w.p. jest konsekwencją zmiany art. 261 u.p.w.p.

Zmiany art. 296 u.p.w.p.:

Ust. 1b ma na celu implementację art. 11 dyrektywy. Przepis dotyczy prawa zakazania czynności przygotowawczych w związku z użyciem opakowania.

Ust. 1c ma na celu implementację art. 12 dyrektywy. Przepis dotyczy reprodukcji znaków towarowych w słownikach, encyklopediach lub podobnych zbiorach informacji.

Ust. 1d i ust. 1e mają na celu implementację art. 10 ust. 4 dyrektywy. Przepisy dotyczą praw wynikających ze znaku towarowego.

Ust. 1 f odnosi się do punktu 25 preambuły do dyrektywy, który dotyczy leków generycznych.

Ust. 2 pkt 3 ma na celu implementację art. 5 ust. 3 lit. a oraz art. 10 ust. 2 lit. c dyrektywy. Przepisy dotyczą ochrony renomowanych znaków towarowych.

Ust. 3 ma na celu dostosowanie ustawy - Prawo własności przemysłowej do wyroku Trybunału Sprawiedliwości Unii Europejskiej z 7 lipca 2016 r. w sprawie C-494/15. W wyroku tym stwierdzono, że art. 11 zdanie trzecie dyrektywy 2004/48/WE Parlamentu Europejskiego i Rady z 29 kwietnia 2004 r. w sprawie egzekwowania praw własności intelektualnej ${ }^{9}$ należy interpretować w ten sposób, że zakresem pojęcia pośrednika, z usług którego korzysta osoba trzecia do naruszenia prawa własności intelektualnej, objęty jest m.in. dzierżawca hal targowych, który poddzierżawia usytuowane w tych halach stanowiska handlowe indywidualnym podmiotom handlującym, spośród których to podmiotów niektóre wykorzystują swe miejsce do sprzedaży towarów będących podróbkami

9 Dz.Urz. UE L 157 z 30 kwietnia 2004 r., s. 45, Dz.Urz. UE, polskie wydanie specjalne: rozdz. 17, t. 2, s. 32 . 
towarów markowych. Trybunał przesądził również, że warunki, którym podlega nakaz skierowany wobec takiego pośrednika, są identyczne z warunkami odnoszącymi się do nakazów, które mogą być skierowane do pośredników na rynku elektronicznym online.

Ust. $3^{1}$ ma na celu implementację art. 18 dyrektywy. Przepis dotyczy ochrony praw właściciela później zarejestrowanego znaku towarowego.

Zmiana art. 305 u.p.w.p. ma na celu doprecyzowanie przepisu przez wyraźne wskazanie, że dotyczy także unijnych znaków towarowych. Przepis ma pośredni związek z dyrektywą (zob. motyw trzeci preambuły). Zmiana nie narusza art. 137 ust. 2 rozporządzenia Parlamentu Europejskiego i Rady (UE) 2017/1001 z 14 czerwca 2017 r. w sprawie znaku towarowego Unii Europejskiej.

\section{Podsumowanie}

Analiza przepisów projektu ustawy potwierdza, że projekt ma na celu wykonanie prawa Unii Europejskiej. Wykonanie dotyczy przede wszystkim dyrektywy 2015/2436, ale także innych aktów prawa Unii Europejskiej oraz aktów prawa międzynarodowego, których stroną jest Unia Europejska. Zdecydowana większość przepisów projektu ustawy ma bezpośredni związek z wykonaniem prawa Unii Europejskiej. W marginalnym zakresie (projektowany art. 224 ust. $2^{2}$ u.p.w.p.) projekt rozciąga implementowane przepisy na inne dziedziny prawa.

Należy uznać, że deklaracja Rady Ministrów, dotycząca wykonującego charakteru projektu ustawy, odpowiada rzeczywistemu celowi regulacji. 